\title{
PLA2R1 wt Allele
}

National Cancer Institute

\section{Source}

National Cancer Institute. PLA2R1 wt Allele. NCI Thesaurus. Code C114546.

Human PLA2R1 wild-type allele is located within 2q23-q24 and is approximately $131 \mathrm{~kb}$ in length. This allele, which encodes secretory phospholipase A2 receptor protein, is involved in phospholipase activity and endocytosis. 